\title{
Changes of retinal oxygen saturation during treatment of diabetic macular edema with a pre-defined regimen of aflibercept: a prospective study
}

\author{
Somar M. Hasan ${ }^{1}$ (D) Martin Hammer ${ }^{1} \cdot$ Daniel Meller $^{1}$ \\ Received: 18 January 2021 / Revised: 22 May 2021 / Accepted: 7 July 2021 / Published online: 1 September 2021 \\ (C) The Author(s) 2021
}

\begin{abstract}
Purpose To study the effect of anti-VEGF therapy for diabetic macular edema (DME) on retinal oxygen saturation $\left(\mathrm{O}_{2} \mathrm{~S}\right)$ and its correlation with functional and anatomical changes of retinal tissue.

Methods An interventional prospective single group study. Included were 10 eyes of 10 patients with visually significant DME which received a fixed regimen of intravitreal aflibercept every 4 weeks for 5 months, followed by 3 injections every 8 weeks, and were controlled monthly. Visual acuity (VA), central retinal thickness (CRT), arterial $\left(\mathrm{aO}_{2} \mathrm{~S}\right)$, venous (vO $\left.{ }_{2} \mathrm{~S}\right)$ and arteriovenous difference $\left(\mathrm{AVdO}_{2} \mathrm{~S}\right)$ retinal oxygen saturation were noted monthly. Changes after 5th (V6) injection and on last followup (V12) were studied. Correlations of different parameters were analyzed.

Results The $\mathrm{aO} 2 \mathrm{~S}$ did not change whereas $\mathrm{vO}_{2} \mathrm{~S}$ decreased $(62.2 \pm 9.4$ pre-op to $57.2 \pm 10.5$ on $\mathrm{V} 6, p=0.03)$. This remained unchanged at $59.4 \pm 13.2$ on V12 $(p=0.2)$ and was accompanied by an increase of $\mathrm{AVdO}_{2} \mathrm{~S}(40.8 \pm 8.3$ pre-op to $44.8 \pm 10.6$, $p=0.03$ on V6) which was followed by a non-significant decrease to $41.8 \pm 11.3$ on V12 $(p=0.06)$. We found no correlation between $\mathrm{BCVA}$ and $\mathrm{aO}_{2} \mathrm{~S}$. However, mild correlation between $\mathrm{BCVA}$ and both $\mathrm{vO}_{2} \mathrm{~S}$ and $\mathrm{AVdO}_{2} \mathrm{~S}(r=-0.2 p=0.035$ and $r=$ $0.185 p=0.05$ respectively) was found. No correlation was found between CRT and $\mathrm{aO}_{2} \mathrm{~S}_{2} \mathrm{vO}_{2} \mathrm{~S}, \mathrm{or} \mathrm{AVdO}_{2} \mathrm{~S}$.

Conclusions During DME treatment with fixed regimen of intravitreal aflibercept over 11 months, we observed a reduction of $\mathrm{vO}_{2} \mathrm{~S}$ and increase of $\mathrm{AVdO}_{2} \mathrm{~S}$ which correlated with BCVA but not CRT. This could be explained by increasing consumption of $\mathrm{O}_{2} \mathrm{~S}$ in the central retina and, possibly, by re-perfusion process.
\end{abstract}

\section{Key messages:}

- Increased levels of retinal venous Oxygen saturation and decreased arterio-venous difference are well documented in diabetic retinopathy. The influence of treatment of diabetic macular edema with anti-VEGF is poorly studied.

- Management of diabetic macular edema with fixed regimen of Aflibercept over 11 months correlated with reducing levels of venous Oxygen saturation and increasing levels ofarterio-venous differences

- Changes of retinal Oxygen saturation correlated with functional parameters as visual acuity but not with anatomical parameters as central retinal thickness

Keywords Diabetic retinopathy $\cdot$ Retinal oxygen saturation · Diabetic macular edema · Anti-VEGF therapy $\cdot$ Aflibercept

Somar M. Hasan

Somar.Hasan@med.uni-jena.de

1 Department of Ophthalmology, Jena University Hospital, Am Klinikum 1, 07747 Jena, Germany

\section{Introduction}

Changes of retinal vessel oxygen saturation $\left(\mathrm{O}_{2} \mathrm{~S}\right)$ are known in eyes with diabetic retinopathy (DR). Increased arterial 
$\left(\mathrm{aO}_{2} \mathrm{~S}\right)$ and venous $\left(\mathrm{vO}_{2} \mathrm{~S}\right)$ retinal oxygen saturation levels and decreased extraction were measured with increasing severity of DR [1-3]. This could be explained by three mechanisms: (1) capillary nonperfusion and shunting, (2) thickening of capillary vessel walls, and (3) greater affinity of hemoglobin $\mathrm{HbA} 1 \mathrm{C}$ for oxygen in diabetic patients $[3,4]$. In eyes with capillary shunting, there is bypassing of blood flow of parts of capillary network resulting in non-perfusion and reduced tissue oxygenation. In addition, thickening of capillary walls results in a higher diffusion barrier for oxygen between vessel lumen and tissue [3]. The presence of diabetic macular edema (DME) correlated with more pronounced increase of venous retinal oxygen saturation and decreased extraction compared with the DR without DME [2,4] and might be explained by reduced retinal autoregulation by increasing severity of diabetic retinopathy [5]. However, a secondary effect of lower oxygen consumption of the central retina as a result of reduced function of the retinal cells cannot be excluded.

The first-line therapy of fovea involving DME is intravitreal injection of vascular endothelial growth factor (VEGF) inhibitors and is known to improve visual acuity and reduce central retinal thickness (CRT). However, it is not known if improvement of visual acuity and reduction of DME correlate with changes of retinal $\mathrm{O}_{2} \mathrm{~S}$. Such correlation might offer new insights which help in understanding the pathophysiology of the disease and its reaction on the anti-VEGF therapy. Treatment of vision threatening DME with 3 monthly injections of intravitreal ranibizumab followed by pro re nata administration did not show significant changes of retinal $\mathrm{O}_{2} \mathrm{~S}$ levels in spite of achieving improvement of visual acuity and reduction of macular edema [6]. Similar results were found after 3 monthly injections of intravitreal aflibercept [7]. On the other hand, studies reporting 12-month outcomes of treatment with ranibizumab or aflibercept showed that improvement of central retinal thickness can progress till month 12 accompanied with improvement of visual acuity $[8,9]$. The aim of this study was to investigate the progression of retinal $\mathrm{O}_{2} \mathrm{~S}$ during a 12-month treatment period of visually significant DME with intravitreal aflibercept using a fixed treatment regimen and to study its correlation with functional (best corrected visual acuity_BCVA) and anatomical (CRT) parameters.

\section{Methods}

This is an interventional prospective single-group non-randomized, non-controlled study. We included patients with non-proliferative diabetic retinopathy and diabetic macular edema involving the fovea and resulting in vision loss. Inclusion and exclusion criteria are listed in Table 1. All patients received a recommended fixed regimen of five intravitreal injections of aflibercept $2 \mathrm{mg} / 0.05 \mathrm{ml}$ (Eylea, Bayer Vital AG, Leverkusen, Germany) every 4 weeks followed by three injections every 8 weeks. Patients were followed monthly according to the pre-defined protocol as shown in Table 2. Before starting treatment, every patient underwent a thorough ocular examination including BCVA determined by ETDRS standards, Goldmann applanation intraocular tonometry, and slitlamp bio-microscopy for the anterior and posterior segment in mydriasis including staging of the DR using ETDRS grading system. $\mathrm{O}_{2} \mathrm{~S}$ was measured and CRT was documented using optical coherence tomography (OCT). All patients underwent fundus fluorescence angiography (FA). These examinations (except for FA) were repeated monthly after the first injection for 11 months.

\section{Measurement of oxygen saturation}

The pupil was dilated with tropicamide $5.0 \mathrm{mg} / \mathrm{mL}$ (Mydrum eye drops; Bausch + Lomb, Berlin, Germany) as the five photos of the retina were taken with the retinal vascular oximeter (IMEDOS Systems UG, Jena, Germany), focusing on the optic nerve head and the parapapillary vessels with intervals of approximately $30 \mathrm{~s}$ between them. Arteries and veins were marked by the same experienced examiner (SMH); and $\mathrm{O} 2 \mathrm{~S}$ in the arteries, veins, and the arteriovenous difference (AV-D) were automatically measured and averaged over a circumpapillary ring with an inner and outer diameter of 2 and 3 disk radii, respectively. The software VesselMap 3.60, a component of the oximeter, was also used. Optical densities of the vessels were measured as the logarithmic ratio of the fundus reflection at the vessel and besides the vessel. To exclude specular reflex from the vessel, pixels with a reflection above $20 \%$ over the mean value were excluded. The ratio of the optical densities at $610 \mathrm{~nm}$ to that at the isosbestic wavelength of $548 \mathrm{~nm}$ is proportional to the vessel hemoglobin oxygen saturation after compensation for vessel diameter and fundus pigmentation. A linear relationship between the optical density ratio and the relative oxygen saturation measure was established by calibration. Vessel tracking and calculation of the oxygen saturation were done automatically by the software of the device. The reproducibility of the measurement was shown to be $2.5 \%$ in arteries and $3.25 \%$ in veins (mean standard deviation of repeated measurements) [10]. Examination was performed in a dark room without any illumination source other than the retinal oximeter.

\section{Optical coherence tomography}

As the pupil was still dilated following $\mathrm{O} 2 \mathrm{~S}$ measurement, OCT examination of the central retina (Cirrus HD-OCT 5000 Carl-Zeiss Meditec, Oberkochen, Germany) with use of the central macular cube settings and help of eye-tracker was performed. Examined central retina was divided using the ETDRS grid and thickness of the central $(1 \mathrm{~mm})$ ring was 
Table 1 Inclusion and exclusion criteria

\begin{tabular}{|c|c|}
\hline \multirow[t]{6}{*}{ Inclusion criteria } & Patients with non-treated diabetic macular edema \\
\hline & Able to sign a written informed consent \\
\hline & Age between 21 and 80 years \\
\hline & Able to complete the study protocol \\
\hline & Best corrected visual acuity between $20 / 400$ and $20 / 25$ in the study eye \\
\hline & Manufacturer's criteria for aflibercept treatment \\
\hline \multirow[t]{13}{*}{ Exclusion criteria } & $\begin{array}{l}\text { Proliferative DR or non-proliferative DR requiring or expected to need laser photocoagu- } \\
\text { lation during the study period. }\end{array}$ \\
\hline & $\begin{array}{l}\text { Any previous ocular surgical intervention other than non-complicated cataract surgery (this } \\
\text { should have been performed } 8 \text { weeks before inclusion) }\end{array}$ \\
\hline & $\begin{array}{l}\text { Any retinal pathology other than DR (vascular occlusion, hereditary retinal dystrophies, } \\
\text { vitreomacular traction, etc.) }\end{array}$ \\
\hline & $\begin{array}{l}\text { Any macular pathology other than DME (any form or stage of macular degeneration, } \\
\text { macular hole, macular edema of other reason than DME .. etc.) }\end{array}$ \\
\hline & Spherical equivalent of more than +6.0 Diopters or less than -3.0 Diopters \\
\hline & Systemic diseases which might affect retinal O2S (COPD, renal insufficiency, etc.) \\
\hline & Hypertension with hypertensive retinopathy $\geq \mathrm{II}^{\circ}$ \\
\hline & History of stroke, transient ischemic attack or myocardial infarction \\
\hline & Status post intravitreal injections \\
\hline & Media opacities affecting fundus examination \\
\hline & Any acute infection of the eye \\
\hline & Advanced glaucoma with a cup to disk excavation $\geq 0.8$ \\
\hline & Pregnancy or lactation \\
\hline
\end{tabular}

Abbreviations: $D R$ diabetic retinopathy documented. Included were only images with a quality of 5/10 or better.

The study was performed in accordance with the Declaration of Helsinki, and a signed informed consent was obtained from all participants before any study related examination was performed. The study protocol was approved by the ethical commission of the Jena university hospital, Germany.

\section{Patients}

The study enrolled 11 eyes of 11 patients with type-2 diabetes and non-proliferative diabetic retinopathy with diabetic macular edema and foveal involvement resulting in reduced visual acuity. One patient was lost from follow-up after the sixth visit because of hospitalization as a complication of her diabetes so that 10 eyes of 10 patients were available at the last visit for statistical analysis. No patient received anti-VEGF therapy to the other eye during study time.

BCVA, CRT, intraocular pressure, and vascular retinal $\mathrm{O}_{2} \mathrm{~S}$ were compared on three time points:

- Before starting treatment (visit 0)

- 4 weeks after the 5 th injection corresponding to month 5 (visit 6), where the maximum effect of aflibercept is expected (4 weeks after the 5 th injection performed every 4 weeks)

Table 2 Study protocol

\begin{tabular}{lllllllllllllll}
\hline & V 0 & V 1 & V 2 & V3 & V 4 & V 5 & V6 & V 7 & V 8 & V 9 & V 10 & V 11 & V 12 \\
\hline IVIA & & $\mathrm{X}$ & $\mathrm{X}$ & $\mathrm{X}$ & $\mathrm{X}$ & $\mathrm{X}$ & & $\mathrm{X}$ & & $\mathrm{X}$ & & $\mathrm{X}$ & \\
Visus & $\mathrm{X}$ & & $\mathrm{X}$ & $\mathrm{X}$ & $\mathrm{X}$ & $\mathrm{X}$ & $\mathrm{X}$ & $\mathrm{X}$ & $\mathrm{X}$ & $\mathrm{X}$ & $\mathrm{X}$ & $\mathrm{X}$ & $\mathrm{X}$ \\
IOP & $\mathrm{X}$ & & $\mathrm{X}$ & $\mathrm{X}$ & $\mathrm{X}$ & $\mathrm{X}$ & $\mathrm{X}$ & $\mathrm{X}$ & $\mathrm{X}$ & $\mathrm{X}$ & $\mathrm{X}$ & $\mathrm{X}$ & $\mathrm{X}$ \\
Slitlamp & $\mathrm{X}$ & & $\mathrm{X}$ & $\mathrm{X}$ & $\mathrm{X}$ & $\mathrm{X}$ & $\mathrm{X}$ & $\mathrm{X}$ & $\mathrm{X}$ & $\mathrm{X}$ & $\mathrm{X}$ & $\mathrm{X}$ & $\mathrm{X}$ \\
$\mathrm{O}_{2} \mathrm{~S}$ & $\mathrm{X}$ & & $\mathrm{X}$ & $\mathrm{X}$ & $\mathrm{X}$ & $\mathrm{X}$ & $\mathrm{X}$ & $\mathrm{X}$ & $\mathrm{X}$ & $\mathrm{X}$ & $\mathrm{X}$ & $\mathrm{X}$ & $\mathrm{X}$ \\
OCT & $\mathrm{X}$ & & $\mathrm{X}$ & $\mathrm{X}$ & $\mathrm{X}$ & $\mathrm{X}$ & $\mathrm{X}$ & $\mathrm{X}$ & $\mathrm{X}$ & $\mathrm{X}$ & $\mathrm{X}$ & $\mathrm{X}$ & $\mathrm{X}$ \\
\hline
\end{tabular}

Abbreviations: IVIA intravitreal injection of aflibercept, IOP intraocular pressure, $\mathrm{O}_{2} \mathrm{~S}$ retinal oxygen saturation, $O C T$ optical coherence tomography 
- 4 weeks after the 8th injection corresponding to month 11 (visit 12), where we wanted to measure the effect of a maintenance dose of 3 injections every 8 weeks

Changes of every visit to the visit before were calculated for each of the different parameters (BCVA, CRT, $\mathrm{aO}_{2} \mathrm{~S}$, $\mathrm{vO}_{2} \mathrm{~S}$, and arteriovenous difference oxygen saturation $\left.\left(\mathrm{AVdO}_{2} \mathrm{~S}\right)\right)$ through all monthly visits. Correlations of these changes were studied.

\section{Statistical analysis}

The statistical analysis was performed using IBM SPSS Statistics Version 22.0 (IBM Corp., Armonk, NY, USA). All parameters were tested for normal distribution (ShapiroWilk test). In normally distributed data, the paired sample $t$ test and Pearson's correlation test were used. Otherwise, Wilcoxon signed-rank and the Spearman correlation tests were used. All results are presented as mean \pm standard deviation. A $p$ value of $\leq 0.05$ was considered significant.

\section{Results}

The basic data of all ten patients before starting therapy are listed in Table 3.

\section{Changes of BCVA, CRT, IOP, and DR}

Changes of these parameters on every visit are listed in Table 4. The BCVA improved on visit 6 from $64.2 \pm 10.3$ pre-op to $69.8 \pm 10.2$ ETDRS letters $(p=0.05)$ and remained stable on visit 12 at $71.0 \pm 9.3$ ETDRS letters $(p>0.05)$. The CRT reduced from $394 \pm 73.9 \mu \mathrm{m}$ pre-op to $308 \pm 73.7$ on visit $6(p=0.009)$ and continued to improve till visit 12 (290.1 $\pm 64.7 \mu \mathrm{m}, p=0.04)$. IOP remained stable at 17.1 $\pm 3.1,17.2 \pm 2.0$, and $17.6 \pm 2.9 \mathrm{mmHg}$ pre-op, on visit 6 and on visit 12 ( $p=0.9$ and 0.7 respectively). No changes of the stage of DR were observed on visit 12 .

\section{Changes of the retinal $\mathrm{O}_{2} \mathrm{~S}$}

The $\mathrm{aO}_{2} \mathrm{~S}$ remained unchanged (pre-op $103.0 \pm 7.1$ to 102.0 \pm 7.3 on visit 6 and to $101.2 \pm 7.6$ on visit $12, p=0.39$ and 0.74 respectively), although showing a downward trend. We observed a significant reduction of $\mathrm{vO}_{2} \mathrm{~S}$ from $62.2 \pm 9.4$ preop to $57.2 \pm 10.5$ on visit $6(p=0.03)$ which then remained unchanged at $59.4 \pm 13.2$ on visit $12(p=0.2)$. This was accompanied by an increase of $\mathrm{AVdO}_{2} \mathrm{~S}$ saturation from $40.8 \pm 8.3$ pre-op to $44.8 \pm 10.6(p=0.03)$ on visit 6 and followed by a non-significant decrease to $41.8 \pm 11.3$ on last visit ( $p=0.06)$ (Fig. 1).

Studying the correlations of changes between the different parameters (change of every visit to the visit before) showed a significant correlation of BCVA with CRT $(r=-0.32, p>$ 0.001 , Pearson correlation test). We found no correlation between BCVA and the $\mathrm{aO}_{2} \mathrm{~S}(p>0.05)$. However, we found a mild but significant correlation between the BCVA and both the $\mathrm{vO}_{2} \mathrm{~S}$ and the $\mathrm{AVdO}_{2} \mathrm{~S}(r=-0.2, p=0.035$ and $r=0.185$, $p=0.05$ respectively). No correlation was found between the CRT and the $\mathrm{aO}_{2} \mathrm{~S}, \mathrm{vO}_{2} \mathrm{~S}$, or $\mathrm{AVdO}_{2} \mathrm{~S}$.

Table 3 Preoperative data of all 10 eyes of 10 patients

\begin{tabular}{|c|c|c|c|c|c|c|c|c|c|c|}
\hline Patient & Sex & Age & Loc & IOP & Stage & CRT & BCVA & $\mathrm{aO}_{2} \mathrm{~S}$ & $\mathrm{vO}_{2} \mathrm{~S}$ & $\mathrm{AVdO}_{2} \mathrm{~S}$ \\
\hline 1 & F & 62 & $\mathrm{~L}$ & 16 & Moderate & 320 & 79 & 100.91 & 65.284 & 35.626 \\
\hline 2 & M & 66 & $\mathrm{R}$ & 20 & Mild & 343 & 72 & 100.566 & 63.614 & 36.952 \\
\hline 3 & $\mathrm{~F}$ & 81 & $\mathrm{~L}$ & 17 & Mild & 463 & 56 & 92.982 & 45.404 & 47.578 \\
\hline 4 & $\mathrm{~F}$ & 65 & $\mathrm{~L}$ & 22 & Severe & 498 & 54 & 100.696 & 70.162 & 30.534 \\
\hline 5 & M & 77 & $\mathrm{~L}$ & 14 & Moderate & 270 & 55 & 108.922 & 69.094 & 39.828 \\
\hline 6 & M & 41 & $\mathrm{R}$ & 21 & Mild & 384 & 75 & 96.342 & 55.971 & 40.371 \\
\hline 7 & F & 60 & $\mathrm{R}$ & 18 & Mild & 390 & 65 & 95.602 & 58.666 & 36.936 \\
\hline 8 & M & 60 & $\mathrm{R}$ & 14 & Severe & 494 & 75 & 112.638 & 58.422 & 54.216 \\
\hline 9 & M & 72 & $\mathrm{~L}$ & 13 & Severe & 395 & 60 & 111.628 & 79.354 & 32.274 \\
\hline 10 & M & 50 & $\mathrm{~L}$ & 16 & Moderate & 383 & 51 & 109.621 & 55.983 & 53.638 \\
\hline Mean \pm STD & & $63.4 \pm 11.9$ & & $\begin{array}{l}17.1 \\
\pm 3.1\end{array}$ & N/A & $394 \pm 73.99$ & $64.2 \pm 10.3$ & $102.99 \pm 7.15$ & $62.19 \pm 9.44$ & $40.79 \pm 8.34$ \\
\hline
\end{tabular}

Abbreviations: $L O C$ localization, $L$ left, $R$ right, $I O P$ intraocular pressure in $\mathrm{mmHg}$, Stage stage of diabetic retinopathy, $C R T$ central retinal thickness in $\mu \mathrm{m}, B C V A$ best corrected visual acuity in ETDRS letters, $a \mathrm{O}_{2} \mathrm{~S}$ arterial retinal oxygen saturation, $\mathrm{vO}_{2} \mathrm{~S}$ venous retinal oxygen saturation, $A V d \mathrm{O}_{2} \mathrm{~S}$ arteriovenous difference of retinal oxygen saturation 


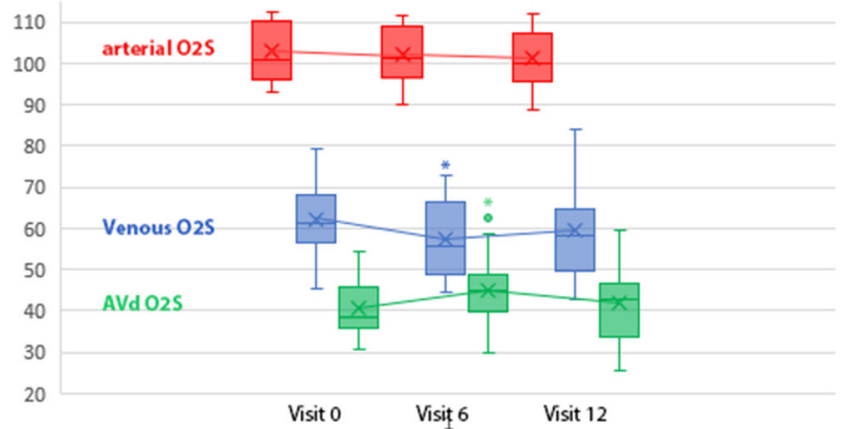

Fig. 1 Progression of retinal oxygen saturation on visit 0 , visit 6 , and visit 12. Graphic generated using IBM SPSS Statistics Version 22.0 (IBM Corp., Armonk, NY, USA). The * sign points to statistically significant difference

\section{Discussion}

Different pathologic features are associated with DR including apoptosis of vascular endothelial cells and pericytes, thickening of basement membrane, capillary occlusion, and break down of the blood-retinal barrier (BRB) [11]. Synthesis of VEGF is upregulated by different mechanisms including tissue hypoxia [12], and its concentrations in diabetic patients are 5 times that of age-matched controls [13]. Treatment of visually significant DME with anti-VEGF is now a standard of care and leads to improvement of VA and reduction of CRT. The effect of anti-VEGF therapy on the retinal oxygen saturation and its correlation with the functional and anatomical changes during therapy is not well studied. In our study, we report for the first time the changes of retinal $\mathrm{O}_{2} \mathrm{~S}$ during treatment of DME with a pre-defined treatment regimen over a 12-month period.

We observed an improvement of the visual acuity from $64.2 \pm 10.34$ letters pre-op to $69.5 \pm 9.7$ on visit 6 and to $71.0 \pm 9.36$ on the last visit. Similar results were found in other studies using aflibercept and giving a mean of 8 injections in 1 year [14]. In other studies, an even further improvement was achieved when using a different treatment protocol which allowed laser photocoagulation and more injections [9]. The central retinal thickness reduced from $394 \pm 73.9 \mu \mathrm{m}$ pre-op to $308 \pm 73.7$ after on visit $6(p=0.009)$ and continued to reduce till last visit to $290.1 \pm 64.7(-104 \mu \mathrm{m}$ on month 12). This is also in accordance with published data [14].

Studying progress of retinal $\mathrm{O}_{2} \mathrm{~S}$, we did not see significant changes of $\mathrm{aO}_{2} \mathrm{~S}$ during treatment course but we observed a significant reduction of $\mathrm{vO}_{2} \mathrm{~S}$, a change of $-8 \%$ which remained stable on last visit and was accompanied by an increase of $\mathrm{AVdO}_{2} \mathrm{~S}$ on visit 6 and remained stable on last visit. This contradicts results of other studies, where a- and $\mathrm{vO}_{2} \mathrm{~S}$ did not change during treatment with aflibercept or ranibizumab. These studies, however, had either a shorter 
follow-up time of 3 months [7], which might not be sufficient in many cases to control the disease and reach the end results functionally or anatomically or used another treatment regimen like a loading dose of 3 injections followed by pro re nata schema and allowed laser photocoagulation after month 3 , resulting in less injections $(6.6 \pm 2.5)$ in 1 year. However, a higher central retinal thickness was found after 6 months $(346.2 \pm 109.4 \mu \mathrm{m})$ compared to our study [6]. The effect of laser photocoagulation on retinal $\mathrm{O}_{2} \mathrm{~S}$ is controversial. This is why patients who might need laser photocoagulation during the study time were excluded in our study $[1,15,16]$.

The decrease of $\mathrm{vO}_{2} \mathrm{~S}$ and increase of $\mathrm{AVdO}_{2} \mathrm{~S}$ could be explained by different mechanisms. (1) Improvement of severity of DR following treatment with anti-VEGF with aflibercept associating with more improvement at year 1 and 2 even in the absence of re-perfusions might have played a role [17, 18], as less severe retinopathy is associated with lower $\mathrm{vO}_{2} \mathrm{~S}$ and higher $\mathrm{AVdO}_{2} \mathrm{~S}[1,2]$. In our study, we did not observe an improvement of the DR but we had 7 of 10 eyes (70\%) with a mild to moderate disease where improvement might not be detected through the ETDRS scale. Eyes with active proliferative DR were excluded from study. (2) A re-perfusion process in areas of non-perfusion after treatment of DR with anti-VEGF [19] was reported, although this is controversial [18]. The reperfusion may result in increased consumption of $\mathrm{O}_{2}$ by the re-perfused retinal areas and reduction of the $\mathrm{vO}_{2} \mathrm{~S}$. These changes of $\mathrm{vO}_{2} \mathrm{~S}$ were not accompanied with changes of $\mathrm{aO}_{2} \mathrm{~S}$ but with an increased $\mathrm{AVdO}_{2} \mathrm{~S}$, which might point to the possibility of increasing oxygen consumption of the retinal tissue during treatment with aflibercept. In mice retinas suffering from oxygen-induced injury and developing hypoxia, Arias et al. reported a significant improvement of the function of amacrine cells measured with electroretinogram after treatment with aflibercept compared with nontreated mice [20]. These changes were accompanied with improvement of the $a$ and $b$ waves pointing to an improved retinal function. Improvement of inner retinal cells, especially amacrine cells, might have led to increased $\mathrm{O}_{2}$ consumption and might partly explain our results.

The $\mathrm{vO}_{2} \mathrm{~S}$ correlated mildly but significantly with the visual acuity. This inverse correlation, where increased visual acuity was associated with lower $\mathrm{vO}_{2} \mathrm{~S}$ levels, could also be explained by increasing $\mathrm{O}_{2}$ consumption as retinal cells restore their function achieving a better BCVA, independent of the central retinal thickness and the anatomical progression of the central retina. It is well known that oxygen consumption is higher in the parafoveal retina compared with the peripheral retina and it even increases in case of hypoxia which is a main component of the pathophysiology of DME [21]. As to our knowledge, our study is the first to report the correlations of the $\mathrm{O}_{2} \mathrm{~S}$ with functional (BCVA) and anatomical (CRT) parameters and to show a significant correlation of the changing $\mathrm{vO}_{2} \mathrm{~S}$ with the visual acuity.
Our study has some limitations: we had a small sample of 10 eyes and studies with larger samples are needed to verify our results. Wide field fluorescein angiography or OCTangiography was not part of our study so that we were not able to evaluate the role of re-perfusion or quantitatively grade the severity of DR in our sample although the clinical grading system which we used showed no changes of the severity of DR during study period. Still, this system does not include assessment of peripheral ischemia and its possible contribution to the changes of $\mathrm{O}_{2} \mathrm{~S}$.

\section{Conclusion}

Our study is the first to report the effect of treatment of eyes with DME with fixed treatment regimen of intravitreal aflibercept on retinal vascular $\mathrm{O}_{2} \mathrm{~S}$ over a 12-month period and to describe its correlation with BCVA and CRT. Reduction of $\mathrm{vO}_{2} \mathrm{~S}$ and increase of $\mathrm{AVdO}_{2} \mathrm{~S}$ over the study period and its correlation with BCVA but not CRT could be explained by increased consumption of $\mathrm{O}_{2} \mathrm{~S}$ in the central retina and, possibly, by a re-perfusion process. Studies with larger sample size and inclusion of wide field angiography and observing changes of DR could offer a verification and additional explanation of our findings.

Funding Open access funding enabled and organized by Projekt DEAL. This was an investigator-initiated study which received a financial supported from Bayer Vital GmbH, Leverkusen, Germany. This support did not affect the design, performance, or the results of the study.

Data availability All collected data are available on demand.

\section{Declarations}

Conflict of interest The authors declare no competing interests.

Consent to participate The study was approved by the ethical commission of the Jena university hospital, Germany.

Consent for publication Consent to publish data was obtained from all patients.

Open Access This article is licensed under a Creative Commons Attribution 4.0 International License, which permits use, sharing, adaptation, distribution and reproduction in any medium or format, as long as you give appropriate credit to the original author(s) and the source, provide a link to the Creative Commons licence, and indicate if changes were made. The images or other third party material in this article are included in the article's Creative Commons licence, unless indicated otherwise in a credit line to the material. If material is not included in the article's Creative Commons licence and your intended use is not permitted by statutory regulation or exceeds the permitted use, you will need to obtain permission directly from the copyright holder. To view a copy of this licence, visit http://creativecommons.org/licenses/by/4.0/. 


\section{References}

1. Hammer M, Vilser W, Riemer T, Mandecka A, Schweitzer D, Kuhn U, Dawczynski J, Liemt F, Strobel J (2009) Diabetic patients with retinopathy show increased retinal venous oxygen saturation. Graefes Arch Clin Exp Ophthalmol 247:1025-1030. https://doi. org/10.1007/s00417-009-1078-6

2. Jorgensen CM, Hardarson SH, Bek T (2014) The oxygen saturation in retinal vessels from diabetic patients depends on the severity and type of vision-threatening retinopathy. Acta Ophthalmol 92:34-39. https://doi.org/10.1111/aos.12283

3. Guduru A, Martz TG, Waters A, Kshirsagar AV, Garg S (2016) Oxygen saturation of retinal vessels in all stages of diabetic retinopathy and correlation to ultra-wide field fluorescein angiography. Invest Ophthalmol Vis Sci 57:5278-5284. https://doi.org/10. 1167/iovs.16-20190

4. Hardarson SH, Stefansson E (2012) Retinal oxygen saturation is altered in diabetic retinopathy. Br J Ophthalmol 96:560-563. https://doi.org/10.1136/bjophthalmol-2011-300640

5. Frederiksen CA, Jeppesen P, Knudsen ST, Poulsen PL, Mogensen CE, Bek T (2006) The blood pressure-induced diameter response of retinal arterioles decreases with increasing diabetic maculopathy. Graefes Arch Clin Exp Ophthalmol 244:1255-1261. https://doi. org/10.1007/s00417-006-0262-1

6. Takasago Y, Fujita T, Nakano Y, Osaka R, Miyake M, Muraoka Y, Tsujikawa A (2019) Ranibizumab treatment improves diabetic macular oedema without influencing retinal oximetry parameters. Acta Ophthalmol 97:e1048-e1053. https://doi.org/10.1111/aos. 14145

7. Blindbaek SL, Peto T, Grauslund J (2020) Correlation between diabetic retinopathy severity and oxygen metabolism in patients with diabetic macular edema during treatment with intravitreal aflibercept. Ophthalmic Res 63:106-113. https://doi.org/10.1159/ 000503930

8. Mitchell P, Bandello F, Schmidt-Erfurth U, Lang GE, Massin P, Schlingemann RO, Sutter F, Simader C, Burian G, Gerstner O, Weichselberger A, group Rs (2011) The RESTORE study: ranibizumab monotherapy or combined with laser versus laser monotherapy for diabetic macular edema. Ophthalmology 118: 615-625. https://doi.org/10.1016/j.ophtha.2011.01.031

9. Diabetic Retinopathy Clinical Research N, Wells JA, Glassman AR, Ayala AR, Jampol LM, Aiello LP, Antoszyk AN, ArnoldBush B, Baker CW, Bressler NM, Browning DJ, Elman MJ, Ferris FL, Friedman SM, Melia M, Pieramici DJ, Sun JK, Beck RW (2015) Aflibercept, bevacizumab, or ranibizumab for diabetic macular edema. N Engl J Med 372:1193-1203. https://doi.org/10. 1056/NEJMoa1414264

10. Hammer M, Vilser W, Riemer T, Schweitzer D (2008) Retinal vessel oximetry-calibration, compensation for vessel diameter and fundus pigmentation, and reproducibility. J Biomed Opt 13: 054015. https://doi.org/10.1117/1.2976032

11. Stewart MW (2014) Anti-VEGF therapy for diabetic macular edema. Curr Diab Rep 14:510. https://doi.org/10.1007/s11892-014$0510-4$
12. Dor Y, Porat R, Keshet E (2001) Vascular endothelial growth factor and vascular adjustments to perturbations in oxygen homeostasis. Am J Physiol Cell Physiol 280:C1367-C1374. https://doi.org/10. 1152/ajpcell.2001.280.6.C1367

13. Funk M, Schmidinger G, Maar N, Bolz M, Benesch T, Zlabinger GJ, Schmidt-Erfurth UM (2010) Angiogenic and inflammatory markers in the intraocular fluid of eyes with diabetic macular edema and influence of therapy with bevacizumab. Retina 30:1412-1419. https://doi.org/10.1097/IAE.0b013e3181e095c0

14. Bhandari S, Nguyen V, Fraser-Bell S, Mehta H, Viola F, Baudin F, Gabrielle PH, Creuzot-Garcher C, Gillies M, Barthelmes D (2020) Ranibizumab or aflibercept for diabetic macular edema: comparison of 1-year outcomes from the Fight Retinal Blindness! Registry. Ophthalmology 127:608-615. https://doi.org/10.1016/j.ophtha. 2019.11.018

15. Torp TL, Kawasaki R, Wong TY, Peto T, Grauslund J (2018) Changes in retinal venular oxygen saturation predict activity of proliferative diabetic retinopathy 3 months after panretinal photocoagulation. Br J Ophthalmol 102:383-387. https://doi.org/10. 1136/bjophthalmol-2017-310576

16. Jorgensen C, Bek T (2014) Increasing oxygen saturation in larger retinal vessels after photocoagulation for diabetic retinopathy. Invest Ophthalmol Vis Sci 55:5365-5369. https://doi.org/10.1167/ iovs.14-14811

17. Bressler SB, Liu D, Glassman AR, Blodi BA, Castellarin AA, Jampol LM, Kaufman PL, Melia M, Singh H, Wells JA, Diabetic Retinopathy Clinical Research N (2017) Change in diabetic retinopathy through 2 years: secondary analysis of a randomized clinical trial comparing aflibercept, bevacizumab, and ranibizumab. JAMA Ophthalmol 135:558-568. https://doi.org/10.1001/ jamaophthalmol.2017.0821

18. Bonnin S, Dupas B, Lavia C, Erginay A, Dhundass M, Couturier A, Gaudric A, Tadayoni R (2019) Anti-vascular endothelial growth factor therapy can improve diabetic retinopathy score without change in retinal perfusion. Retina 39:426-434. https://doi.org/10. 1097/IAE.0000000000002422

19. Levin AM, Rusu I, Orlin A, Gupta MP, Coombs P, D'Amico DJ, Kiss S (2017) Retinal reperfusion in diabetic retinopathy following treatment with anti-VEGF intravitreal injections. Clin Ophthalmol 11:193-200. https://doi.org/10.2147/OPTH.S118807

20. Rojo Arias JE, Economopoulou M, Juarez Lopez DA, Kurzbach A, Au Yeung KH, Englmaier V, Merdausl M, Schaarschmidt M, Ader M, Morawietz H, Funk RHW, Jaszai J (2020) VEGF-Trap is a potent modulator of vasoregenerative responses and protects dopaminergic amacrine network integrity in degenerative ischemic neovascular retinopathy. J Neurochem 153:390-412. https://doi. org/10.1111/jnc. 14875

21. Yu DY, Cringle SJ, Su EN (2005) Intraretinal oxygen distribution in the monkey retina and the response to systemic hyperoxia. Invest Ophthalmol Vis Sci 46:4728-4733. https://doi.org/10.1167/iovs. 05-0694

Publisher's note Springer Nature remains neutral with regard to jurisdictional claims in published maps and institutional affiliations. 